\title{
Persepsi Merek Dalam Pemilihan Air Minum Dalam Kemasan (Studi Pada Mahasiswa Universitas Islam Balitar Blitar)
}

\author{
Denok Wahyudi Setyo Rahayu \\ Fakultas Ekonomi Universitas Islam Balitar \\ email: denok.wahyudisr@gmail.com
}

\begin{tabular}{l}
\hline Kata kunci: \\
Persepsi \\
Merek \\
Produk \\
Konsumen \\
\hline
\end{tabular}

\section{Keywords:}

Perception

The brand

Product

Consumer

Rahayu, D. W. S. (2020).

Persepsi Merek Dalam Pemilihan Air Minum Dalam Kemasan

(Studi Pada Mahasiswa Universitas Islam Balitar Blitar). Akuntabilitas: Jurnal Ilmiah Ilmu-Ilmu Ekonomi,13(1), 81-89

\begin{abstract}
ABSTRAK
Merek menjadi hal penting bagi konsumen dalam memilih suatu produk. Merek AMDK yang beraneka ragam dapat memberikan konsumen alternatif pilihan produk mana yang akan dikonsumsi. Tujuan penelitian adalah untuk mengetahui persepsi merek bagi konsumen dalam memilih produk AMDK. Metode penelitian menggunakan pengamatan langsung dan kuisioner kepada mahasiswa selaku konsumen AMDK di Universitas Islam Balitar. Populasi penelitian adalah mahasiswa Universitas Islam Balitar. Teknik sampling menggunakan accidental sampling yaitu mahasiswa yang secara kebetulan bertemu dengan peneliti. Variabel yang digunakan adalah persepsi merek. Hasil penelitian menunjukkan bahwa persepsi merek dapat mempengaruhi konsumen dalam memilih produk AMDK. Produk Aqua merupakan merek AMDK yang banyak diminati konsumen, sedangkan Le Mineral, Cleo, Ades, dan Vit memiliki peminat setelah Aqua. Responden lain cenderung mengkonsumsi merek AMDK secara bergantian karena menganggap semua merek sama.
\end{abstract}

\section{ABSTRACT}

The brand becomes important for consumers in choosing a product. The wide range of bottled drinking water brands can give consumers an alternative choice of which products to consume. The purpose of this study was to determine the brand's perception for consumers in choosing bottled water products. The research method uses direct observation and questionnaires to students as consumers of bottled water at Balitar Islamic University. The research population was Balitar Islamic University students. The sampling technique uses accidental sampling, namely students who accidentally meet with researchers. The variable used is brand perception. The results showed that brand perception can influence consumers in choosing bottled water products. Aqua product is a brand of bottled drinking water that is in high demand by consumers, while Le Minerals, Cleo, Ades, and Vit are interested after Aqua. Other respondents tend to consume the bottled drinking water brand in turn because they consider all brands the same. 


\section{PENDAHULUAN}

Merek sebagai dasar konsumen dalam pemilihan produk. Adanya merek membuat produk menjadi lebih dikenal oleh konsumen. Pentingnya merek menjadi alasan produsen harus memberikan nama pada produk yang dihasilkan. Merek merupakan nama, istilah, tanda, lambang, disain, atau gabungan antara semuanya dengan harapan dapat mengidentifikasi barang maupun jasa yang dihasilkan atau dijual produsen serta dapat membedakan barang atau jasa dari produk pesaing (Nugrahaini dkk, 2014: 189-201).

Merek merupakan nama, istilah, tanda, simbol, rancangan, atau kombinasi dari semuanya, yang dimaksudkan untuk mengidentifikasikan barang atau jasa atau kelompok penjual dan untuk mendiferensiasikannya (membedakan) dari barang atau jasa pesaing (Kotler, 2009:332). Merek dapat membedakan produk maupun jasa sebuah perusahaan dari produk saingannya (Tengor dkk, 367-375). Pesaing menjadi hal yang harus diantasipasi oleh produsen. Keberadaan merek dapat menjadi hal menarik bagi konumen dalam menentukan pilihan produk yang akan dikonsumsi. Suatu merek sebagai janji yang harus dipenuhi produsen (Maulana, 2012).

Air minum dalam kemasan (AMDK) merupakan produk yang memiliki merek. Keberadaan merek pada air minum tersebut dapat memberikan perbedaan antara produk satu dengan yang lainnya. Konsumen dipermudah dengan penggunaan merek tersebut. Konsumen dapat memilih dan mengkonsumsi produk AMDK tersebut sesuai dengan persepsi merek pilihan. Proses persepsi diawali oleh stimuli yang mengenai panca indera dari konsumen (Suryani, 2013 : 75), stimuli tersebut merangsang konsumen dalam menetukan produk pilihan.

Berbagai pilihan merek AMDK tersaji di pasar. Konsumen dapat memilih sesuai selera. Hubungan suatu merek terhadap konsumen akan dirasakan semakin kuat jika didasarkan pada suatu pengalaman maupun informasi yang banyak diperoleh konsumen (Supriyadi, dkk., 2016 : 135-144). Keberagaman promosi, harga, kemasan dan variabel lain yang menempel di AMDK menjadi penarik bagi konsumen untuk membeli. Variabel tersebut menjadi sarana penjualan yang baik. Kepiawaian produsen dalam memuat variabel pada produk AMDK yang diproduksi harus tersaji sehingga konsumen tertarik untuk membeli. 
Ronitua, A., Brida, L., dan Barry, H (2017 : 113-120) dalam penelitian memperoleh hasil brand image mempunyai pengaruh yang signifikan terhadap keputusan pembelian Le Minerale, beberapa faktor lainnya yang memberi pengaruh yaitu harga dan kualitas. Yusa, DY dkk (2018 : 69-80) pada hasil penelitian yang dilakukan diperoleh hasil variabel citra merek, harga, dan promosi memiliki pengaruh terhadap keputusan pembelian AMDK Rivero di Bandar Lampung. Ghealita, V dan Setyorini, R (2015 : 1-9) menunjukkan hasil penelitian yaitu brand awareness berpengaruh secara signifikan pada sikap pengambilan keputusan dalam pembelian AMDK merek Aqua pada masyarakat Kota Bandung, hal tersebut terjadi karena merek telah melekat di benak masyarakat.

Mahasiswa Universitas Islam Balitar sebagai pengguna produk AMDK. Mahasiswa selaku konsumen dapat memilih sesuai kebutuhan dan keinginan. Berbagai merek yang terdapat di pasar menjadi pilihan mahasiswa selaku konsumen. Merek AMDK yang terdapat di pasar menjadi alternatif pilihan mahasiswa. Persepsi pemilihan akan merek AMDK menjadi kajian dalam penelitian yang dilakukan.

\section{Gambar 1 \\ Kerangka Konsep}
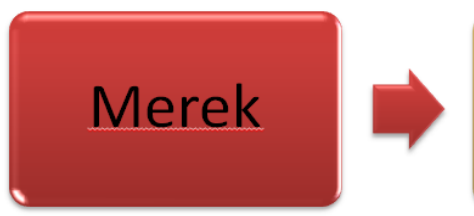

\section{Pemilihan Produk}

\section{Persepsi Merek}

\section{Sumber : Kerangka Konsep, diolah, 2020.}

Gambar 1, terdapat variabel merek yang terarah pada pemilihan produk dan berlanjut pada persepsi merek. Merek sebagai kajian penelitian diharapkan dapat menjadi penentu bagi konsumen dalam memilih produk, sehingga akan mengarah pada persepsi merek berdasarkan produk pilihan tersebut. Merek yang dimaksud adalah merek AMDK yang dikonsumsi oleh responden.

\section{METODE PENELITIAN}

Roscoe (Sugiyono, 2007:74) menyatakan pengambilan sampel bahwa ukuran sampel dinyatakan layak adalah 30 sampai 500 responden. Populasi penelitian adalah mahasiswa Universitas Islam Balitar. Sampel penelitian menggunakan Persepsi Merk Dalam Pemilihan Air Minum Dalam Kemasan (Studi Pada Mahasiswa Universitas Islam Balitar Blitar) 
acidental sampling yaitu mahasiswa yang kebetulan bertemu dengan peneliti saat penelitian dilakukan dan sesuai dengan sumber data yang dibutuhkan oleh peneliti. Pengambilan data melalui pengamatan dan kuisioner. Teknik analisis data menggunakan penyajian data sebagai berikut :

(1) Tabulasi data

(2) Distribusi frekuensi data

(3) Penyajian data dalam bentuk diagram batang dan pie chart

(4) Pembahasan hasil

Tabulasi data merupakan langkah awal untuk mengelompokkan data berdasarkan produk pilihan responden. Distribusi frekuensi data sebagai upaya untuk melihat nilai prosentase data sehingga akan terlihat merek apa yang cenderung menonjol menjadi pilihan responden melalui nilai prosentase. Diagram batang dan pie chart merupakan diagram yang digunakan untuk mengetahui nilai persepsi responden yang disajikan dalam bentuk gambar. Pembahasan hasil merupakan ulasan dari hasil penelitian dan dikaitkan dengan penelitian terdahulu.

\section{PEMBAHASAN}

Penelitian dilakukan dengan melibatkan 61 responden selaku konsumen AMDK. Melalui pengamatan langsung dan pemberian kuisioner, terlihat beberapa merek yang menjadi pilihan konsumen. Berdasarkan penelitian tersebut, maka hasil yang diperoleh bahwa produk merek Aqua, Le Minerale, Cleo, Ades, dan Vit menjadi merek AMDK yang cenderung dikonsumsi oleh responden. Selain merek tersebut, ada pula konsumen yang menyatakan mengkonsumsi semua merek karena beranggapan merek - merek AMDK dirasa sama dan nilai loyal tidak diperlukan.

Berikut data hasil penelitian :

Tabel 1

Tabulasi Data Pilihan Merek AMDK

\begin{tabular}{|l|l|}
\hline Merek AMDK & Responden \\
\hline Aqua & 27 \\
\hline Le Minerale & 22 \\
\hline Cleo & 3 \\
\hline
\end{tabular}

Persepsi Merk Dalam Pemilihan Air Minum Dalam Kemasan (Studi Pada Mahasiswa Universitas Islam Balitar Blitar) 


\begin{tabular}{|l|l|}
\hline Ades & 1 \\
\hline Vit & 1 \\
\hline Bergantian merek & 7 \\
\hline Jumlah & $\mathbf{6 1}$ \\
\hline
\end{tabular}

Sumber : data penelitian, diolah, 2020.

Tabel 1 menunjukkan bahwa terdapat 5 merek AMDK yang cenderung dikonsumsi oleh responden, yaitu : Aqua (27 responden), Le Minerale (22 responden), Cleo (3 responden), Ades (1 responden), Vit (1 responden), dan sisanya adalah responden bergantian merek (7 responden).

\section{Gambar 2}

Distribusi Frekuensi Data Pilihan Merek AMDK

\begin{tabular}{|l|l|l|}
\hline Merek AMDK & Responden & Prosentase (\%) \\
\hline Aqua & 27 & 44,26 \\
\hline Le Minerale & 22 & 36,06 \\
\hline Cleo & 3 & 4,92 \\
\hline Ades & 1 & 1,64 \\
\hline Vit & 1 & 1,64 \\
\hline Bergantian merek & 7 & 11,48 \\
\hline Jumlah & $\mathbf{6 1}$ & $\mathbf{1 0 0}$ \\
\hline
\end{tabular}

Sumber : data penelitian, diolah, 2020.

Gambar 2 terdapat data yang menunjukkan nilai pemilihan AMDK Aqua dengan 27 responden (44,26\%), Le Minerale dengan 22 responden (36,06\%), Cleo dengan 3 responden (4,92\%), Ades dengan 1 responden $(1,64 \%)$, Vit dengan 1 responden $(1,64 \%)$, dan bergantian merek dengan 7 responden $(11,48 \%)$. Gambar 3 menunjukkan AMDK Aqua memiliki nilai paling tinggi yaitu sebesar 27 responden, Le Minerale dengan 22 responden, bergantian merek dengan 7 responden, Cleo dengan 3 responden, sedang Ades dan Vit dengan 1 responden sehingga total responden adalah 61 responden. Gambar 4, Pie Chart menunjukkan 
bahwa produk AMDK merek Aqua memiliki responden terbesar, dilanjut Le Mineral, Cleo, Ades, dan Vit, sedang sisanya sebanyak 11,48\% mengkonsumsi semua merek secara bergantian.

\section{Gambar 3 \\ Diagram Batang Pilihan Merek AMDK}

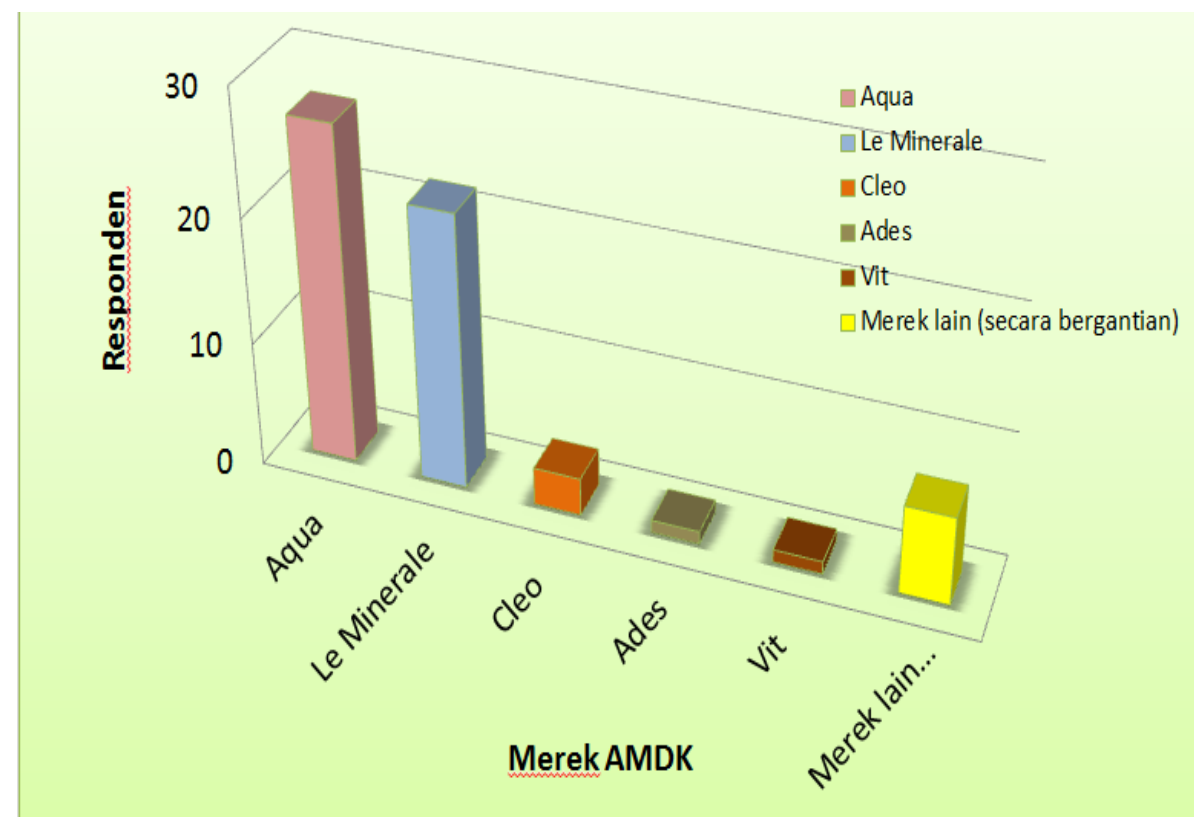

Sumber : data penelitian, diolah, 2020.

Gambar 4

Pie Chart Pilihan Merek AMDK

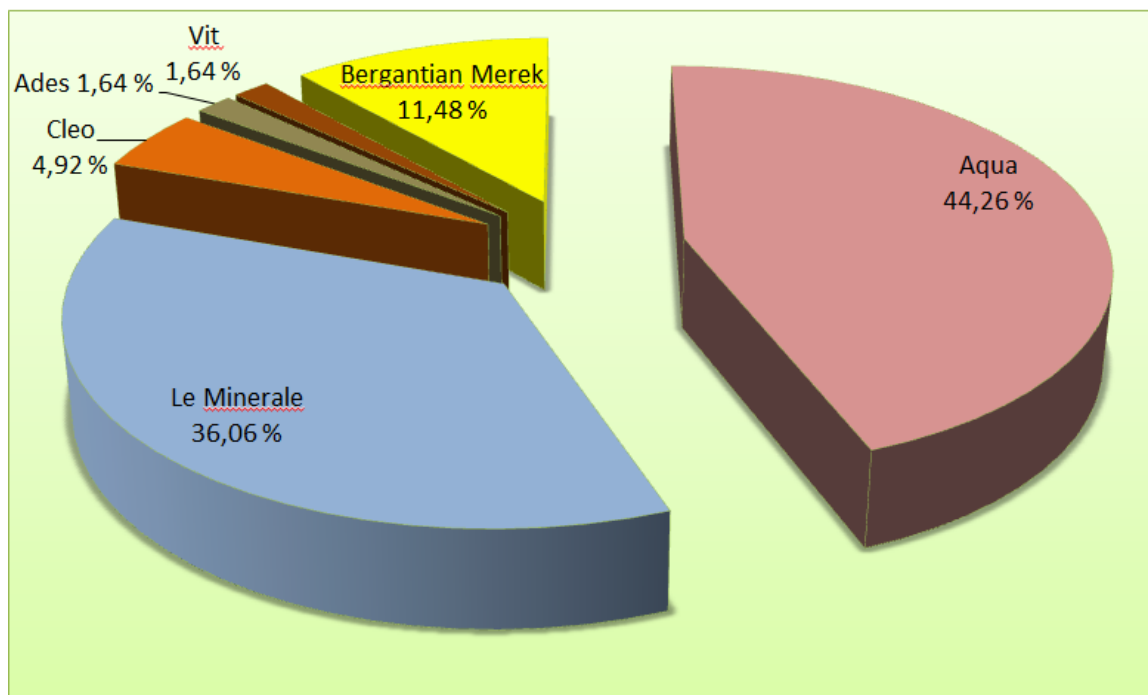

Sumber : data penelitian, diolah, 2020. 
Merek menjadi pembeda produk atau jasa perusahaan dari produk pesaing. Berdasarkan data yang diperoleh diketahui bahwa konsumen cenderung lebih menyukai untuk mengkonsumsi AMDK merek Aqua (44,26\%), dilanjutkan Le Minerale (36,06\%), Cleo (4,92\%), Ades (1,64\%), Vit (1,64\%), sedang sisanya sebanyak 11 responden $(11,48 \%)$ cenderung mengkonsumsi merek AMDK dengan bergantian.

Dalam pemilhan AMDK, konsumen cenderung memilih produk yang sudah dikenal lama dan menjadi kebiasan atau dengan kata lain sering dikonsumsi, promosi yang menarik, higienis, kemasan menarik, kualitas AMDK menjadi alasan konsumen dalam menentukan suatu merek AMDK. Aqua merupakan produk dengan penilaian konsumen memiliki nilai lebih dibanding dengan produk lainnya, yaitu produk pertama sebagai AMDK dan selalu berupaya meningkatkan kualitas supaya konsumen puas dengan produk yang dihasilkan, promosi, kebiasan konsumen, dan produk higienis. Selain itu, Aqua sebagai merek pengganti dalam menyebutkan nama produk AMDK.

Meski demikian, produk merek lain seperti Le Minerale, Cleo, Ades, dan Vit tetp memiliki konsumen sendiri. Alasan konsumen dalam memilih produk selain Aqua antara lain terpengaruh iklan tentang rasa air mineral yang baik untuk dikonsumsi adalah terdapat rasa manis, kemasan ramah lingkungan, untuk pengobatan dan sebagainya.

Namun, perlu diketahui bahwa terdapat pula konsumen yang mengkonsumsi produk AMDK secara bergantian dengan alasan seperti keinginan mengkonsumi atau merasakan produk lain, sikap tidak loyal, serta menganggap semua air mineral sama sehingga konsumen akan cenderung lebih sering bergantian dalam mengkonsumsi produk AMDK.

Hasil penelitian yang dilakukan sesuai dengan hasil penelitian dari Ronitua, A., Brida, L., dan Barry, H (2017 : 113-120), Yusa, DY dkk (2018 : 69-80) ,Ghealita, V dan Setyorini, R (2015 : 1-9) yang menyatakan merek dapat memberi dorongan bagi konsumen dalam memilih produk AMDK, sehingga persepsi konsumen terhadap merek AMDK penting dalam keputusan pengambilan sikap pada produk AMDK merek apa yang akan dikonsumsi. 


\section{KESIMPULAN}

Merek menjadi suatu hal penting bagi seorang atau sekelompok konsumen dalam memilih suatu produk. Persepsi akan suatu merek dapat membawa konsumen untuk memberi keputusan akan membeli atau tidak terhadap produk yang dimaksud. AMDK merupakan produk air minum yang sering dikonsumsi konsumen. Mahasiswa Universitas Islam Balitar selaku responden penelitian menunjukkan kecenderungan memilih Aqua daripada produk yang lain. Aqua sebagai produk pertama AMDK dan selalu berupaya meningkatkan kualitas supaya konsumen puas dengan produk yang dihasilkan, kebiasan konsumen, produk higienis, serta merupakan merek pengganti dalam menyebutkan nama produk AMDK.

Produk Le Minerale, Cleo, Ades, dan Vit tetap memiliki konsumen tersendiri. Alasan karena faktor iklan yang memberi informasi bahwa air minum yang baik adalah terdapat rasa manis, adanya nilai ramah lingkungan, dan untuk pengobatan. Selain itu, adapula konsumen yang lebih memilih mengkonsumsi secara bergantian karena memiliki anggapan semua AMDK adalah sama dan keinginan untuk mencoba produk lain.

\section{DAFTAR PUSTAKA}

Ghealita, V dan Setyorini, S. (2015). Pengaruh Brand Awareness Terhadap Keputusan pembelian AMDK Merek Aqua ( Studi Pada Masyarakat di Kota Bandung). Image (Jurnal Riset Manajemen), 4 (1), 1-9.

Kotler, Philip. (2009). Manajemen Pemasaran. Jakarta: Erlangga.

Maulana, E. Amalia. (2012). Brandmate : Mengubah Just Friend Menjadi Soulmate. Etnomark Consulting : Tangerang.

Nugrahaini, R. L., Adiarni, N., dan Najamuddin,M. (2014). Analissi penguatan merek dalam membentuk ekuitas merek pada minuman sari buah BB (Studi kasus : Mahasiswa (end user) di Fakultas Sains dan Teknologi). Jurnal Agribisnis, 8(2), 189-201.

Ronitua, A., Brida, L., dan Barry,H. (2017). Pengaruh Brand Image Terhadap Keputusan Pembelian Air Minum Dalam Kemasan Merek Le Minerale. Epigram, 14(2), 113 - 120.

Sugiyono. (2007). Metode Penelitian Kuantitatif, Kualitatif dan RED. Bandung : Alfabeta. 
Supriyadi, Yuntawati Fristin, dan Ginanjar Indra KN. (2016). Pengaruh Kualitas Poduk Dan Brand Image Terhadap Keputusan pembelian (Studi PadaMahasiswa Pengguna Produk Sepatu Merek Converse di Fisip Universitas Merdeka Malang. Jurnal Bisnis dan Mnaajemen, 3 (1), 135 - 144.

Suryani, Tatik. (2013). Perilaku Konsumen Di Era Internet : Implikasinya Pada Strategi Pemasran. Yogyakarta : Graha Ilmu.

Tengor, G., Kawet, L., dan Loindong, S. (2016). Pengaruh Merek, Desain Dan Kualitas Produk Terhadap Keputusan Pembelian Iphone Studi Kasus Pada Mahasiswa Stie Eben Haezar Manado. Jurnal Berkala Ilmiah Efisiensi, 16 (04), 367-375.

Yusa, VD dan Anugrah LH. (2018). Pengaruh Citra Merek, Harga, dan Promosi Dalam Keputusan Pembelian Air Minum Dalam Kemasan (AMDK) Rivero di Bandar Lampung. Jurnal Derivatif, 12 (1), 69-80. 